\title{
O pensamento de Alberto Torres e a educação rural no Brasil: contribuições ao surgimento do ruralismo pedagógico
}

Marcelo Augusto Totti*

Vitor Machado**

\author{
Introdução
}

Este artigo pretende retomar o pensamento de Alberto Torres em sua originalidade, diferentemente do que convencionalmente vem sendo apontado na literatura - como pensador meramente positivista e autoritário- mas procurando observálo de uma perspectiva mais ampla, como um intelectual que defendia a educação rural como instrumento fundamental de construção da nação e que estava visivelmente preocupado com a defesa dos recursos naturais, em um período onde pouco, ou quase nada, se discutia sobre a questão ambiental no Brasil.

As reflexões aqui desenvolvidas nos levaram a crer que as ideias defendidas por Alberto Torres abriram caminho para o surgimento de um importante movimento ocorrido na educação brasileira, durante o governo de Getúlio Vargas (1930-45), denominado de Ruralismo Pedagógico, o qual visava à educação do rurícola, evitando que ele pudesse migrar do campo para a cidade.

No entanto, antes de refletirmos sobre esse significativo momento da história da educação brasileira, faz-se necessário recordarmos aqui, de maneira sucinta, a biografia de Alberto Torres, por considerarmos que foi justamente ela que o fez um pensador preocupado com questões socioambientais e educativas, que se mostraram inéditas para a sua época.

\section{Alberto Torres e sua trajetória política e intelectual}

Alberto Torres foi um intelectual preocupado com as grandes questões nacionais. Advogado de formação, foi militante da causa republicana e abolicionista,

\footnotetext{
* Doutor e Mestre e em Educação Escolar. Professor junto ao Departamento de Sociologia e Antropologia da FFC/Unesp-Campus de Marília, líder do grupo de pesquisa Intelectuais, esquerdas e movimentos sociais, atuando principalmente nos seguintes temas:Fernando de Azevedo, Florestan Fernandes, pensamento social e educacional no Brasil.E-mail: totti101@bol.com.br

** Doutor em Educação, Mestre em Sociologia, professor do Departamento de Educação, da Faculdade de Ciências da UNESP /Campus de Bauru. Tem experiência na área da Sociologia da Educação, com ênfase em Educação em Assentamentos Rurais. E-mail: vitor@fc.unesp.br
} 
fundou o periódico $O$ Povo (grifos nossos), órgão de imprensa que seria um instrumento de luta contra a monarquia e a escravidão.

Após a proclamação da República, engaja-se na política fluminense, tendo sido deputado federal em 1894 e Ministro da Justiça e Negócios Interiores do governo Prudente de Moraes (1896).

Sua experiência política chega ao ápice com a eleição de Presidente do Estado do Rio de Janeiro, em 1897, aos 30 anos de idade, com mandato de 1897 a 1900. De comportamento austero e avesso às conciliações e concessões da política local, sofre um mandato conturbado, passando por um processo de impeachment, que resultou em insucesso por parte de seus opositores. Sua administração pauta-se pelo papel nacionalista e intervencionista do Estado, regulando a comercialização do café e defendendo o trabalhador rural brasileiro, em detrimento da influência do trabalhador imigrante.

Nesta carreira notável faltava-lhe a experiência no judiciário, que foi conquistada com a nomeação em 1901, aos 35 anos de idade, para ser Ministro do Supremo Tribunal Federal. Sua passagem pela Suprema Corte foi cercada de julgamentos polêmicos como o banimento da família imperial do território brasileiro, mas sempre tendo como norte a defesa da liberdade individual e soberania do país.

Essa vivência nas três esferas da nascente estrutura republicana permitiu-lhe um olhar diferenciado do Brasil de sua época. Sua preocupação partia de uma constatação conjuntural da sociedade brasileira: a falta de organização e unidade eram os entraves a serem vencidos para o desenvolvimento do país. "Em termos gerais, sua interpretação do Brasil retratava o país caótico e desorganizado, mas com possibilidades de se deixar conduzir por alguns homens eficientes" (REZENDE, 2000, p. 36).

Por sua vez, a intelectualidade do período estava aquém dos desafios da nação, alheia à vida da sociedade, refletindo-se "no pensamento de todos, sob as formas do diletantismo e do pessimismo" (TORRES, 1982, p.86). O desconhecimento por parte dos intelectuais acerca da realidade brasileira e a importação de teorias europeias incompatíveis com nossa realidade, ocasionava uma incapacidade de construção de uma cultura sólida e a impossibilidade de se criar uma consciência nacional capaz de dar respostas aos grandes problemas nacionais.

Neste sentido, a educação viria a cumprir para Alberto Torres, um importante papel, de dar suporte ao homem do campo evitando o êxodo rural e proporcionando a 
defesa da nossa terra e dos recursos naturais que dela provém. No entender de Torres (1982), ambos são patrimônios do povo, os quais ao serem preservados garantiriam a organização e a soberania do país.

\section{O ideário intelectual de Alberto Torres e a defesa das riquezas nacionais}

O panorama intelectual da primeira República estava profundamente marcado por sua conjuntura histórica. O país vivia um esgotamento da política extrativista e houve o aumento da política de exportações subvencionada pelo Estado, em especial a do café, para suprir as demandas do mercado interno e da elite paulista: "A política de valorização do café constitui um dos exemplos mais nítidos do papel de São Paulo na Federação e das relações entre os vários Estados” (FAUSTO, 2001, p. 150).

A política de valorização do café ${ }^{\text {i }}$ consistia na compra desse produto pelo governo, sempre que houvesse queda do seu preço no mercado externo, sempre com o intuito de promover a defesa dessa importante e valorosa mercadoria. Tal medida tinha a finalidade de garantir a alta dos preços para exportação, através da limitação de sua oferta, fortalecendo as oligarquias: "com o declínio dos preços do produto, a burguesia cafeeira dos principais estados produtores, São Paulo, Rio de Janeiro e Minas Gerais, utilizou seu controle sobre o aparelho do Estado e sua hegemonia sobre as demais frações das classes dominantes" (CUNHA, 2007, p.141).

A aliança com Minas Gerais garantia ao Estado de São Paulo a hegemonia política ${ }^{2}$ devido ao acordo que firmava a alternância no poder federal entre esses dois Estados e representava a figura dos coronéis e sua relação sociopolítica mais geral, o clientelismoz, exercendo forte influência na Câmara Federal, incumbida de reconhecer a eleição dos deputados, afinal "o Executivo se comprometia a excluir os que não fossem do agrado dos governadores" (LAMOUNIER, 2005, p. 98). Essa relação, resultante da desigualdade social, impossibilitava os cidadãos de exercerem a plena democracia, pois os coronéis controlavam o voto na sua área de influência.

A decadência da política cafeeira forçou um redirecionamento na política econômica, diminuindo a atividade exportadora, sendo compensado com o aumento das importações e do comércio de cabotagem, o que resultou no avanço da atividade portuária na cidade do Rio de Janeiro. A cidade carioca tendo a sede do Banco do Brasil, da maior bolsa de valores do país, configurava-se como o grande setor financeiro da nação. No entanto, era necessário transformá-la em um grande centro cosmopolita, 
modificando hábitos, costumes e a sua própria estética, fazendo aparentar uma ideia de progresso, de civilização, para quando os navios europeus aportassem na cidade seus tripulantes se sentissem em Paris, ou seja, em sua própria casa.

Dessa forma, efetivou-se uma expulsão dos grupos populares do centro da cidade, colocada em prática pelos governos municipal e federal, apoiada irrestritamente pela elite e parte da imprensa carioca. A cidade do Rio de Janeiro precisava estar limpa e higienizada para o recebimento dos visitantes europeus. Houve uma remodelação da estrutura arquitetônica do centro da cidade, identificando-a com a estrutura parisiense, estabelecendo-se uma lei de conduta, como explica Sevcenko:

o resultado mais concreto desse processo de aburguesamento intensivo da paisagem foi a criação de um espaço público central na cidade, completamente remodelado, embelezado, jardinado e europeizado, que se desejou garantir com exclusividade para o convívio dos 'argentário' ... o auge desse comportamento mental cosmopolita coincidira com o início da Grande Guerra - quando as pessoas na avenida, ao se cruzarem, em lugar do convencional 'boa tarde' ou 'boa noite' trocavam um 'Viva a França'. (SEVCENKO, 1983, p.34).

Essa era a característica definidora da Primeira República. Assimilação de todo e qualquer tipo de padrão europeu, chegando-se ao ponto da população fluminense trocar o "boa noite" pelo "Viva a França". A sociedade brasileira passou então a ser marcada por uma face conservadora, atrasada, regida por um imperialismo velado nos costumes e hábitos, sustentada por uma elite oligárquica, corporativista e tradicionalista (TOTTI, 2003).

A manutenção dessa política garantiu o primeiro surto industrial no país e com o capital acumulado do café foi possível importar maquinário para a indústria e atender a demanda de um mercado interno nascente, os investimentos em estradas de ferro e a imigração $0^{ \pm}$garantiam a oferta de mão de obra necessária para o desenvolvimento da indústria.

Torres foi profundo crítico dessa política. $\mathrm{Na}$ sua visão seria um equívoco afirmar que as estradas, por exemplo, criariam uma logística necessária capaz de impulsionar o desenvolvimento e a prosperidade do país. O que ocorreu foi meramente uma intensificação da exploração. Para ele:

A prosperidade econômica manifesta-se com o desenvolvimento dos dois fatores: produção e consumo, quando representa o uso, generalizado na sociedade de coisas que interessam à vida sã, e encontra sua expressão de equilíbrio na compensação das perdas da produção exportadas por entradas 
equivalentes, e sua expressão de prosperidade, quando as entradas representam valor superior às perdas resultantes da extração, cultura e comércio das que exportam (TORRES, 1978, p.190).

Como um dos precursores do pensamento sociológico no Brasil, Alberto Torres defende um desenvolvimento para o mercado interno e que a produção de nossa riqueza fosse gerada e consumida pelos brasileiros, o que não ocorria com a sucessão de governos na República, que acabava por favorecer indústrias incipientes e o capital estrangeiro "em prejuízo da agricultura que fazia a vocação nacional” (ROCHA, 2004, p.46).

O capital estrangeiro explorava nossas riquezas naturais, captando nossos recursos sem ter a preocupação com o meio ambientes: "As riquezas naturais, sob quaisquer formas, são patrimônio do povo que habita o território nacional" (TORRES, 1982, p.91).

O uso predatório do solo, das riquezas contidas nele e no subsolo, fruto da ambição pessoal e individual dilapidada em proveito próprio levaria a uma escassez de recursos, esgotamento do potencial de riqueza e uma própria crise econômica como ocorreu "na cultura de borracha, entregues a estrangeiros, na Amazônia" (TORRES, 1982, p.93).

O problema se agravava devido à influência estrangeira, que agia com uma política colonialista que apenas removia e usufruía dos recursos naturais sem compromissos com a nação. Essa política voltada aos interesses do capital estrangeiro, atrelada à devastação de recursos naturais gerava um país sem rumo, conforme explica Torres (1978, p. 63):

Somos um país sem direção política e sem orientação social e econômica. Este é o espírito que cumpre criar. O patriotismo sem bússola, a ciência sem síntese, as letras sem ideal, a economia sem solidariedade, as finanças sem continuidade, a educação sem sistema, o trabalho e a produção sem harmonia e sem apoio, atuam como elementos contrários e desconexos, destroem-se reciprocamente, e os egoísmo e interesses ilegítimos florescem, sobre a ruína da vida comum.

Mas esse tom de pessimismo é substituído quando Alberto Torres comenta o desenvolvimento intelectual advindo com a República. Porém, o surgimento de uma inteligência não estava diretamente relacionado com a República. Os debates ocorridos em torno da abolição da escravatura originaram as primeiras tentativas de explorar a reflexão sociológica como crítica social. O movimento abolicionista cria uma massa crítica que induz a "primeira grande experiência histórica de populações urbanas ou 
rural urbanas brasileiras na esfera da secularização do pensamento e dos modos de entender o funcionamento das instituições" (FERNANDES, 1958, p.195).

Com o movimento abolicionista começa-se a questionar os valores ligados à sociedade escravocrata, devido as incompatibilidades e contradições impostas por uma nascente sociedade moderna com trabalho livre em contraposição a ordem senhoril da escravatura.

Apesar de destacar a importância do surgimento de uma intelectualidade, Alberto Torres criticava duramente os intelectuais do período republicano por expressarem opiniões e teorias distantes da realidade brasileira. Segundo ele, tais intelectualidades ao "se deixarem seduzir 'pelas modas europeias', constroem teorias desvinculadas da nossa realidade" (MARTINI, 2002, p.2).

Torres criticava o fato de nossa intelectualidade desconhecer a realidade nacional e consequentemente não conseguir construir uma cultura própria. A "nossa ilustração é hoje, vaga, fluida, sem assento, não dominando nenhum interesse por habilitar os espíritos a formar juízos e a inspirar atos" (TORRES, 1982, p. 15). A intelectualidade que dirigiria os rumos do país não detinha as condições necessárias para enfrentar os problemas do Brasil, pois era superficial, formada no ensino verbalista, retórico e preocupada "fundamentalmente em exibicionismos e em debates que viessem glorificar suas ideias e convicções" (REZENDE, 2000, p.44). A maioria dos intelectuais carecia do conhecimento da realidade brasileira, já que era um conhecimento teórico importado.

\footnotetext{
A vida cerebral do Brasil gira em torno de dois centros: o mundo dos intelectuais e o dos governantes; os escritores, professores, homens de letras e de ciência, os artistas, no primeiro grupo; os políticos, os administradores, os funcionários, no segundo. E esta vida, inteiramente alheia à vida da sociedade, reflete-se, entretanto, no pensamento de todos, sob as formas do diletantismo e do pessimismo, que traduzem a sensação indefinida de que essas coisas não são as que deveriam interessar (TORRES, 1982, p.86).
}

A intelectualidade havia se perdido em utopias, construções teóricas sem relação com a realidade, o que deixou a inteligência nacional híbrida, ganhando em variedade $\mathrm{e}$ perdendo em precisão, sendo incapaz de programar novos rumos ao país.

O corpo diretivo do país também padecia da mesma letargia. Ao fazer uma comparação histórica dos processos jurídicos de alguns países, Alberto Torres demonstra que o legislador inglês, suíço, norte-americano ${ }^{6}$, tem uma ideia geral da lei 
que não é distante da realidade econômica social destes países, pelo contrário, há uma aproximação entre ideias e fatos.

Havia, no Brasil, uma total alienação dos mecanismos representativos, do conjunto das relações político-jurídicas e de suas relações com a realidade. A alienação estava levando a nação à perda da autonomia, à subalternidade de um país débil em decisões fundamentais para o futuro da nação.

Para a correção de rumos era necessário constituirmos uma nação em que prevalecessem os interesses coletivos da sociedade brasileira. A questão primordial era como construir uma nação sem povo.

Para Torres, nossa nacionalidade era formada por classes e não pelo povo, as classes tinham interesses divergentes sobre o processo decisório do país, em conflito, poderiam levar a desagregação do mesmo.

A necessidade de converter as classes em povo "pressupunha harmonização e homogeneização não econômica, social ou política, mas sim de valores e interesses cívicos, morais e patrióticos." (REZENDE, 2000, p.45). Era necessária a criação de um corpo de valores que integrasse a sociedade, sendo o Estado promotor de políticas públicas que levassem à transformação da sociedade brasileira. Alberto Torres é a inflexão desse paradigma republicano, sua visão funda-se na necessidade de incorporar o povo à nação.

Torres amplia essa discussão conectando-a a noção de civilização, que deveria ser um processo dinâmico, equilibrado e de harmonia entre os direitos individuais dos homens, o meio físico e a sociedade "capaz de assegurar bem-estar e cultura ao indivíduo e desenvolvimento à espécie, conservando e melhorando o patrimônio cósmico da humanidade e aperfeiçoado o seu patrimônio mental" (TORRES, 1978, p.179).

Rocha (2004), ao comentar essa relação entre indivíduo e sociedade no pensamento de Torres, salienta que o pensador trata de tal tema de forma dialética, quando procura demonstrar que os padrões sociais interferem na conduta dos indivíduos ao mesmo tempo em que os procedimentos sociais também teriam interferências individuais e seriam conduzidos por paixões, interesses, amizades. Essa visão leva Torres a uma noção da impossibilidade de criar consensos, destaca Rocha (2004, p.47), pois "o que há de consenso na política da nação é o interesse indiscutível de seu povo, de sua terra, de sua nacionalidade". 


\section{A educação rural na República Velha (1889 - 1930): priorizando a elite rural brasileira}

Em 1889, ao final do Império e início da República no Brasil, ocorreram importantes transformações na sociedade brasileira, que colocaram o país no rumo da modernização e criaram novas necessidades para a população, provocando na elite e nos donos do poder uma grande preocupação com a assistência técnica e a instrução pública (SZMRECSÁNYI, QUEDA, 1976). Segundo esses autores, as origens da assistência técnica data do momento da vinda da família real Portuguesa para o Brasil, quando foi criado o primeiro órgão público do setor, o Jardim Botânico do Rio de Janeiro, teve sua fundação em 1808, com o objetivo de atender a interesses econômicos e científicos. Ele significou, de acordo com Speyer (1983), um sistema paralelo de educação, devido à enorme distância entre a realidade rural e o sistema educacional vigente na época. Já a instrução pública, ou seja, os investimentos do Estado em educação, conforme Szmrecsányi e Queda (1976) ocorreram em torno da educação rural, durante o Império e a República Velha, portanto anterior a 1930, e deram-se nos setores do ensino médio e superior, com um grande destaque para esse último. Conforme apontam, o ensino técnico agrícola, de nível médio, especificamente o curso de agricultura, foi criado pela primeira vez na Bahia, ainda no reinado de D.João VI e depois transformado em 1875 , no Instituto Imperial Baiano de Agricultura, tornando-se mais tarde a primeira escola de agronomia do país. Foram criadas também, em 1883, a escola de agronomia de Pelotas, no Rio Grande do Sul e, em 1901, a escola de agronomia de Piracicaba, localizada no interior do Estado de São Paulo.

De acordo com os autores referendados, podemos constatar que as mudanças no ensino médio e superior estavam voltadas às necessidades da elite agrícola. Elas habitavam a zona rural do país e comandavam a sua economia de característica agro exportadora. Somente, porém, após a criação do Ministério da Agricultura, em 1906, foi sancionada uma legislação federal para regulamentar a formação de técnicos agrícolas, com ensino baseado no modelo francês. Essas escolas não se multiplicaram pelo Brasil. Somente as escolas de ensino superior se multiplicaram, o que pode ser comprovado pela criação de um grande número de escolas particulares, fundadas por missionários protestantes norte americanos, entre 1910 e 1930, em vários estados brasileiros, como o que ocorreu no estado de Minas Gerais, especificamente na cidade de Lavras (1907), em Porto Alegre, Rio de Janeiro (a atual Universidade Rural), Fortaleza, Minas Gerais (Viçosa) e Curitiba. 
É importante ressaltar que, com a implantação da República, além das universidades, as cidades também cresceram muito e se desenvolveram, graças aos investimentos de recursos financeiros advindos dos lucros da agricultura cafeeira.

Por isso, durante longo tempo a implantação do ensino primário rural ficou estagnado, ao passo que as escolas de ensino elementar e cursos técnicos só se multiplicavam nos centros urbanos.

Mas, com o passar dos anos, as discussões sobre a educação pública estavam cada vez mais presentes no cenário nacional. Como afirma Speyer (1983), se durante os anos do Império a elite não concordava com a instrução do povo, ao final dele, ela passa a crer que somente a educação popular poderia trazer o desenvolvimento material do país, e deste modo, logo nos primeiros anos da República, tratou-se de oficializar o sistema dualista de ensino, estabelecendo a diferença entre a educação da classe dominante e a educação popular, ou seja, aquela destinada às classes espoliadas da sociedade. Essa distinção ficou marcada pelo tipo de escola destinada a cada uma delas: a classe dominante frequentava as escolas secundárias acadêmicas e escolas superiores e o povo as escolas primárias e as escolas profissionais urbanas.

É neste período que os Estados brasileiros vão ter autonomia para implantar o seu sistema de ensino, de acordo com a concepção que cada um deles tinha acerca da atividade educativa.

Conforme Romanelli (1988, p. 41)

\begin{abstract}
à União cabia criar e controlar a instrução superior em toda a Nação, bem como criar e controlar o ensino secundário acadêmico e a instrução em todos os níveis do Distrito Federal, e aos Estados cabia criar e controlar o ensino primário e o ensino profissional, que, na época, compreendia principalmente escolas normais de nível médio para moças e escolas técnicas para rapazes.
\end{abstract}

Essa situação, de certa forma, contribuiu para a consolidação dos princípios federalistas propostos pela Primeira República e institucionalizou o direito de autonomia dos estados, no que tange à organização do ensino. Porém, um sistema educacional ligado ao poder central só vai surgir a partir da década de 30, quando se inicia a segunda fase da República e ocorrem mudanças bastante significativas para a população do meio rural.

Assim, as mudanças em torno da educação rural durante a Primeira República (1889-1930) não tiveram êxito, pelo fato da elite rural sentir-se ameaçada com reformas 
que não significavam, nem ao menos tinham qualquer relação com seus valores e padrões de mentalidade.

Outra questão relevante é que a autonomia dos Estados gerou profundas diferenças regionais no processo educativo da população brasileira, devido ao fato de alguns Estados da Federação investirem e equiparem seus sistemas de ensino mais do que outros. Fica evidente que os Estados que comandavam a economia e a política da nação, por possuírem maiores recursos e legislações pertinentes, foram capazes de equipar e desenvolver melhor seu sistema de ensino (SPEYER, 1983).

Quando observamos a trajetória histórica da educação rural no Brasil, até esse momento, podemos notar que ela vai se organizar de acordo com a visão aristocrática de uma elite agrária, a qual comandava uma economia agrário-exportadora e cujo índice de urbanização e industrialização era indiscutivelmente baixo.

Mas, após a Primeira Guerra Mundial (1914-1917), o Brasil passaria por grandes transformações, devido às consequências políticas e econômicas que a guerra acarretou, possibilitando, a partir de 1920 no país, o surgimento de uma nova discussão sobre a educação e o analfabetismo da população.

É nesse período que surgem os primeiros profissionais da educação

a introduzirem ideias da escola renovada, estimulando preocupações com a qualidade do ensino; a origem de todos os nossos problemas é atribuída a precária situação do ensino no país e iniciam-se as primeiras campanhas contra o analfabetismo (SPEYER, 1983, p. 67).

De acordo com a autora em destaque, podemos verificar uma grande preocupação dos educadores com a universalização do ensino, o que possibilitou o avanço do processo educativo no Brasil a partir de 1920, resultando inclusive, no surgimento da Radiodifusão Educativa, em 1923, no Rio de Janeiro, cujos programas tinham como objetivo levar ao público a transmissão de aulas, palestras e conferências.

Porém, é importante relatar que não houve qualquer preocupação com a clientela rural naquele momento, tornando-a, mais uma vez, excluída do sistema de ensino, ignorando grande parcela da população que habitava o campo. Isto quer dizer que os sistemas educacionais atendiam mais as camadas urbanas do que propriamente as rurais. Embora necessitassem de instrução, a educação aos menos privilegiados era somente oferecida em escolas isoladas, compostas por uma só classe, na qual, normalmente, ministravam aulas professores improvisados. 


\section{A contribuição de Alberto Torres para a educação rural na República Velha}

Segundo Torres (1978, p. 188), a questão educacional descrita acima, surge de uma reflexão política mais ampla, sobre a fragilidade de se ampliar os processos decisórios da nascente República ${ }^{9}$ que estariam sustentadas em um povo sem instrução, pois os nossos políticos não haviam se dado conta de que o Brasil precisava "constituir seu povo, dotando as classes pobres da sociedade desse mínimo de segurança e bemestar".

Desse modo, para o autor supracitado, a questão da educação desdobra-se em duas ideias, conforme explica Rocha (2004, p.18): "1) da exigência da incorporação do povo à nação; 2) da insuficiência do povo para o exercício da cidadania" (2004, p.18).

Podemos então dizer que, nos primeiros anos da República, a difusão no meio popular, do acesso à leitura e à escrita, começa a se efetivar como instrumentos cada vez mais valorizados para se incorporar o povo à nação, sendo "a educação popular uma das bandeiras de luta dos liberais republicanos" (SOUZA, 1998, p. 34).

Para Moraes (2006, p.151), a preocupação com a educação popular tinha como finalidade politizar o povo para inseri-lo nos processos decisórios frente ao Estado, permitindo o alargamento da cidadania que seria o sufrágio universal, "oferecendo a virtualidade da participação política a segmentos maiores das classes subalternas -, ao mesmo tempo em que converte o Estado no instrumento mantenedor dessa participação" (MORAES, 2006, p.152).

Essa participação política era restrita, pois a função dos eleitores não era a do exercício pleno da cidadania, mas apenas a escolha da elite que iria decidir, pelo povo, os rumos do país. Desta maneira, os republicanos começam a defender a obrigatoriedade do ensino como um imperativo para a constituição da nacionalidade e como responsabilidade para o exercício da cidadania.

A relação entre a democracia e a obrigatoriedade do ensino não estavam relacionados no discurso republicano, pois a educação popular não advém como pressão das classes mais baixas, mas como instrumento corretor oferecido pelas elites para levar um mínimo de cultura às massas incultas do país. 
A defesa do ensino obrigatório desvenda, por um lado, a intenção de universalização do saber dessa classe dominante, que se apresenta como o único saber legítimo, em oposição ao 'não saber', à 'ignorância' do povo, o que justificaria a necessidade de dirigi-lo do alto. (MORAES, 2006, p.151)

A educação seria obra de ingerência estatal, sem impedir a livre iniciativa particular, pois os republicanos não pregavam o monopólio do ensino, mas a atuação firme do Estado, controlando conteúdos e traçando normas e regras para as escolas.

É neste panorama que se insere a posição de Torres. Para ele, o liberalismo e o velho constitucionalismo inglês, estariam em contradição com a situação brasileira. $\mathrm{O}$ liberalismo só havia colaborado para o enfraquecimento do governo na formação moral e no desenvolvimento do indivíduo. Sendo assim, Torres propõe que o Estado deva atuar afirmativamente, como órgão central de todas as funções sociais, coordenando, harmonizando e regendo a sociedade:

no Brasil, onde a sociedade não chegou a reunir sequer os elementos agregantes da tradição - nem a sociedade existe, nem o Estado; e Estado e sociedade hão de organizar-se, reciprocamente, por um processo mútuo de formação e de educação. Educação pela consciência e pelo exercício, o que vale dizer por um programa, isto é, por uma política: eis o meio de transubstanciar este gigante desagregado em uma nacionalidade (TORRES, 1978, p.37).

Apesar de destacar que a sociedade e o Estado deveriam caminhar juntos, certamente o Estado tem uma prevalência maior no pensamento de Alberto Torres. Em outras sociedades com maior maturidade, a formação delas deu-se pela força contra outras sociedades, uma força corporificada na figura do Estado que teria presença ativa na vida coletiva do povo. Neste sentido, não há sociedade livre e democrática sem a participação efetiva do Estado como órgão regulador da vida coletiva do povo.

O Estado é o grande poder diretivo da sociedade. A partir dele que se deve superar e resolver conflitos e "cabe ao Estado formar o povo, e o que ele ${ }^{\Perp}$ chama de democracia política é incapaz de levar adiante tal tarefa" (SOUZA, 2005, p.305), sendo substituída pela democracia social alcançada por um Estado forte e interventor, que significaria "a corporificação da vida coletiva de um dado povo, para que modelasse o governo como órgão do regime jurídico e social" (REZENDE, 2000, p. 37).

Nesta perspectiva, Alberto Torres avaliava a necessidade de organização nacional e intervenção do Estado na questão educacional: 
A intervenção de que aqui se cogita é, em primeiro lugar, de natureza eminentemente política; a primeira função da União é, neste particular, de direção e de orientação; mas seu dever não se pode limitar a isso, cumprindolhe promover, subsidiariamente, nos Estados, a educação e a cultura dos brasileiros (TORRES, 1978, p.231).

Em sua ótica, o autor propõe uma intervenção estatal que possibilite condições de educação e cultura aos brasileiros. Para ele essa política intervencionista não é ingênua e pressupõem a coparticipação dos entes da federação, tendo em vista, o único critério que julgava eficaz, "de uma séria política de desenvolvimento de nossa cultura[...] que era [...]o critério nacional" (TORRES, 1978, p.94).

A ideia do nacional $\Perp$ está intimamente ligada à vocação agrícola do país, que para Torres foi pré-determinada devido à "fatalidade geográfica e às contingências históricas de nossa formação" (ALMEIDA, 1944, p.216).

Para Vianna (1997, p.181), Alberto Torres praticamente defendia o Estado nacional como arauto do desenvolvimento educacional, proclamando uma verdadeira via prussiana, onde cabia à educação e à sociologia não "informar a sociedade, mas ao Estado, porque seria da ação pedagógica deste, que emergiria a nação". Essa visão decorre de observações feitas por Torres a partir de 1870, com a criação da Diretoria Geral de Estatísticas. Por meio dela começaram a ser divulgados dados sobre a escolarização, os quais mesmo não contendo a precisão adequada, passaram a dar uma visão estatística do ensino público, primário e secundário, revelando um perfil da educação do país. Como afirma Bomeny (2001, p.12 - grifos do autor): "com todas as ressalvas técnicas que se possa fazer aos resultados da apuração, os dados obtidos em 1906, publicados em 1916 em Estatística da Instrução, são suficientes para que tenhamos desenhada a cara de um país que fazia da educação um privilégio de muito poucos"

Os dados da escolarização revelaram que o principal obstáculo ao desenvolvimento cultural era o analfabetismo. Segundo os dados, "74,6\% da população em idade escolar eram analfabetos no início do século XX” (BOMENY, 2001, p.12). Além desses dados alarmantes, outro dado que teve grande importância foi o que mostrou a predominância da população rural no Brasil, pois $80 \%$ dela vivia na zonal rural, dificultando o acesso aos embrionários grupos escolares ${ }^{12}$.

A Constituição de $1891^{\underline{13}}$, conforme já apontado anteriormente, tomando como referência a ideia de descentralização e federalização, passou a responsabilidade da 
educação primária e secundária para o encargo dos Estados, ficando o executivo federal com a incumbência de cuidar do ensino superior, o que gerou uma grande discrepância. Os Estados mais pobres exibiram índices cada vez maiores de analfabetismo e fracasso escolar (BOMENY, 2001), o que gerou uma profunda crítica de Alberto Torres:

O analfabetismo, ou o simples ensino, mais pernicioso que útil, do alfabeto e das quatro operações, a carência dos primeiros elementos da saúde e da vida moral, do senso, da iniciativa e da ambição, fazem do nosso povo um imenso rebanho de corpos exangues e de almas desfalecidas (TORRES, 1978, p.128).

$\mathrm{O}$ analfabetismo acentuava as desigualdades regionais, acarretando a inexistência de um sistema nacional de educação que pudesse contribuir para sanar as deficiências da escolarização no país. Como aponta Torres, isso gerava uma massa de desvanecidos de orientação e incapazes de liderar os seus próprios rumos, sequer o do país. Para ele esses dados foram resultado de uma política de improviso, pois com a abolição da escravatura ${ }^{14}$ - uma das aspirações morais da República - não se planejou uma política de inclusão dos ex-escravos. Além disso, tal política privilegiou políticos e estadistas, ao invés de favorecer a produção, substituindo a mão de obra nacional pelos imigrantes, colocando à margem da sociedade os ex-escravos e agregados que ficaram jogados à própria sorte:

\footnotetext{
o povo brasileiro continuou a ser essa mistura, incongruente e sem alma: um grupo numeroso de intelectuais, uma exorbitante massa de diplomados, pequena camada de industriais e de comerciantes, nas cidades, e, pelo extenso território, donos de fazendas, explorando as terras, uma em exuberância de frutificação, outras quase ressequidas, com o braço imperito do colono; e por toda a parte, multidões de indivíduos, sem profissão, sem alimento, vivendo quase ao ar livre, em muitos lugares realmente nômades, analfabetos, sem notícia da vida e a uma légua de distância, sem consciência do dia seguinte (TORRES, 1978, p.101).
}

A sociedade brasileira era uma nação sem povo, carente em inúmeros aspectos. Faltava-lhe a identidade, a vinculação necessária para a construção do povo em consonância com a nação. Essa vinculação, na visão de Torres, estava ligada à terra, à vocação agrícola e patriótica do país, pois "abandonando a terra, e não cuidando da nação, abandonamos a Pátria, porque a Pátria é a terra, como habitat, mas principalmente, o sentimento e para a razão, isto é, a gente" (TORRES, 1982, p.17). 
Torres acreditava em uma política educacional que estivesse fundamentada em bases mais amplas de proteção social, com objetivos de evitar o êxodo rural. Conforme atesta Marson:

O programa de fixação do trabalhador rural em ocupações ativas e compensadoras, mais a distribuição de terras, torna-se um grande apelo de 'retorno ao campo' no velho axioma fisiocrático, acompanhado da 'modernização' das cidades rurais. O melhoramento das condições materiais e sociais da vida rural, tarefa do Estado, dirige-se especialmente a atrair as populações aglomeradas nas cidades (MARSON, 1979, p.175).

A fixação do homem no campo tinha como objetivo manter a paz social: a propriedade seria uma sedução poderosa a manter o homem no campo, pois as razões desse "êxodo se manifesta, entre nós, como uma verdadeira repugnância pelo trabalho rural, é que as condições econômicas e sociais da vida agrícola repelem os habitantes, sem educação apropriada para amá-la e para exercê-la, em meio e terras não estudados." (TORRES, 1978, p.231).

Ao manter o homem no campo, evitar-se-iam os possíveis conflitos sociais nascentes com a gestação do operariado urbano. Isso se justifica dado ao fato de que, na visão de Torres (1978, p. 47), em conjunto com o operariado urbano viriam as moléstias do seu tempo: anarquismo, socialismo, os quais "propagados entre os operários, tomou a feição dos programas radicais europeus, ampliado até a aspiração do poder".

Para executar seu projeto de política rural seria necessário que os "governos velassem pela educação e seleção intelectual da sociedade, facilitando aos capazes menos afortunados o acesso às escolas e aos cursos superiores" (TORRES, 1978, p.105).

A critica desenvolvida por Torres (1978, p.230) é que os governos da nascente República, favoreceriam os colonos estrangeiros dando-lhes propriedades, instrumentos de trabalho, escolas, o que assumia "proporções de escândalo", pois ao Estado cabia cumprir a função de garantir igualdade de possibilidades e meios de trabalho e prosperidade, ao invés de manter uma política de relações desiguais.

Desse modo, ele defende uma educação profissional aos pequenos lavradores e a educação popular para fixar o homem ao campo e como um dos fatores de organização nacional.

Para realizar a política educativa do país, orientada pelo escopo do preparo geral das populações para a vida agrícola, cumpre estabelecer severas medidas de seleção, em todas as camadas da sociedade, das verdadeiras 
aptidões e capacidades para os estudos da sociedade, dificultando-se aos menos aptos acesso a esses estudos. A instrução secundária e a superior são hoje privilégio e destino dos filhos abastados; injustiça e perda de valores intelectuais para o país, por um lado, com desastrosa influência de incapazes, por outro lado, deslocação, afinal, para as letras e profissões liberais, duma enorme massa de brasileiros (TORRES, 1978, p.231).

Essa política educacional de Torres prevê dois pontos básicos: o primeiro é uma política destinada às populações rurais e a segunda é a criação de métodos de seleção capazes de eleger os melhores e os mais capazes a continuar nos sistemas de ensino. O que ocorria no período era uma seleção econômica e sem critérios intelectuais, desvirtuando os valores éticos e morais da educação.

A preocupação de Torres com a educação estava voltada para a organização e unidade nacional, tomando como referência a realidade vigente, o patriotismo, como formas de despertar no povo brasileiro a consciência nacional rumo a uma grande nação. Destaca Torres: "educar o patriotismo é a função dos diretores de opinião, mas educá-lo austera e positivamente, sobre a base da realidade das nossas coisas, para que daí possa surgir a consciência de nossa verdadeira posição no mundo, a de nossos destinos" (TORRES, 1978, p.103).

\section{O surgimento do Ruralismo Pedagógico}

Apesar, conforme já salientamos nas seções anteriores, do Brasil ter-se caracterizado por uma economia exclusivamente agroexportadora, durante a primeira fase da República, devido às características de uma população concentrada no meio rural e de uma economia que atendia aos interesses dos fazendeiros de café, os quais priorizavam a grande propriedade e a monocultura, foi só na terceira década desse período, em 1920, que se iniciou, na sociedade brasileira, um processo migratório do campo para a cidade.

A partir de 1930, esse movimento passou a ser muito mais intenso, devido ao desenvolvimento industrial gerado pelo governo nacionalista de Getúlio Vargas, o qual pôs fim na hegemonia da oligarquia cafeeira, dando início à era Vargas, cujo governo foi apoiado por uma recém formada elite industrial.

Segundo Leite (2002, p. 28):

Dado o comprometimento dessas elites com a visão urbano-industrial que se cristalizou no país nas primeiras décadas do século, a concentração dos esforços políticos e administrativos ficou vinculada às expectativas metropolitanas, de modo que a sociedade brasileira somente despertou para 
a educação rural por ocasião do forte movimento migratório interno dos anos 1910/20, quando um grande número de rurícolas deixou o campo em busca das áreas onde se iniciava um processo de industrialização mais amplo.

Preocupada, então, em fixar o homem rural à terra, a classe dominante, deu início a um lento movimento para concretizar e sedimentar tal processo $\stackrel{15}{ }$. Esse movimento parecia ser a solução encontrada pela elite para interromper o processo migratório e modificar a vida social do homem rural.

É nesse contexto que surge o chamado "Ruralismo Pedagógico",

[...] movimento que teve como finalidade "ruralizar o ensino primário", fazendo que este se transformasse em instrumento de fixação do homem no campo, na busca de esvaziar as correntes migratórias. [...] houve também a preocupação com a modernização da vida social e econômica do meio rural (SPEYER, 1993, p.69).

Porém, podemos dizer que o Ruralismo Pedagógico não teve êxito, na sua tentativa de fixar o homem no campo, pelo fato da preocupação central dos ruralistas estar voltada muito mais a princípios econômicos e políticos do que humanistas e culturais. Tal movimento propôs transformações no âmbito da educação escolar, obtendo vários adeptos e contribuiu, segundo Szmrecsányi e Queda (1976), para conservar a política educacional agrícola até a década de 1960.

Desta forma, os ruralistas, que tinham como perfil ideológico a defesa do nacionalismo, entendiam que a solução para se evitar o processo de industrialização e modernização dependente pelo qual o país passava, deveria se dar através da fixação do homem ao campo e esse resultado poderia ser obtido por uma pedagogia a ser aplicada nas escolas rurais (BEZERRA NETO, 2003).

Em outros termos, o que se

\begin{abstract}
pretendia era transformar a natureza da escolarização, até então praticada, buscando a implementação de um ensino que se mostrasse eficaz para o homem do campo e que não fizesse a propaganda da cidade, com vistas a atrair o trabalhador rural para os grandes centros urbanos (BEZERRA NETO, 2003, p. 22).
\end{abstract}

Como a preocupação da elite nacional em manter o homem no campo estava diretamente vinculada a questões políticas e econômicas, o Ruralismo Pedagógico não promoveu as mudanças reais propostas por seus idealizadores, o que pode ser 
evidentemente comprovado pela diminuição da população do meio rural e o aumento constante da população urbana.

Mesmo com o golpe de Estado imposto por Getúlio Vargas em 1930 e a criação, no mesmo ano, do Ministério da Educação e Saúde, responsável por inúmeras reformas, a situação de inferioridade entre a educação rural e a educação urbana ainda permanecia. As escolas estavam concentradas nas regiões urbanas de maior densidade demográfica, devido à grande concentração de indústrias. Isso ocorreu também, porque a escolarização urbana passou a fazer parte do ideário político e econômico de desenvolvimento industrial proposto pelo governo getulista, comprometido com as elites do país, o que contribuiu para o fortalecimento e a perpetuação da contradição entre o campo e a cidade, a qual tornou-se mais evidente em 1934, quando foram elaborados projetos especiais e setoriais sob o patrocínio do Ministério da Agricultura que promoveram a criação de colônias agrícolas e a realização de cursos de formação profissional voltado aos trabalhadores rurais (CALAZANS, 1993).

É só em 1937, no regime de ditadura do Estado Novo, implantado por Getúlio Vargas, que o Estado volta sua atenção para a educação rural, com a criação, nesse mesmo ano, da Sociedade Brasileira de Educação Rural, a qual tinha como maior objetivo expandir o ensino e preservar a cultura e o folclore rural. A política educacional do Estado Novo getulista garantia, ainda, a escolaridade e a obrigatoriedade do ensino, dando ênfase ao trabalho manual e ao ensino vocacional das escolas urbanas, destinadas, especialmente, às classes populares. É importante ressaltar que, nesse momento, está explicitamente colocado o papel ideológico da escola rural que pretendia alfabetizar sem se descuidar dos princípios norteadores de moral e civismo (PALMEIRA, 1990).

Para Calazans (1993), a necessidade da classe dominante em manter o rurícola no campo fez com que políticos e educadores sugerissem uma educação que reforçasse os valores rurais, criando e adaptando programas e currículos ao meio físico e à cultura rural.

O mais importante é que, com o passar do tempo, a luta e o debate em torno da educação rural no Brasil vai demonstrar que

não se tratava mais de um movimento alfabetizador, mas sim da origem de uma nova concepção de expansão escolar, em que o rural e o agrícola fossem respeitados nas suas características fundamentais e nas suas necessidades específicas. (CALAZANS, 1993, p. 25) 
Um acontecimento que tratou de reforçar a preocupação com a necessidade da expansão da escola rural foi a realização do VIII Congresso Brasileiro de Educação, que aconteceu em 1942 e assumindo um discurso conservador-nacionalista. Nesse evento, os participantes não definiram claramente as concretas necessidades da escola rural, porém sabiam que ela era essencial para a manutenção do status quo e do próprio Estado, reafirmando a postura ideológica da nova elite em ascensão.

Pode-se considerar que nesse Congresso predominaram as principais ideias do Ruralismo Pedagógico e seus participantes aderiram à ideia de uma escola que ruralizasse o rural, com a criação de uma nova escola que, adaptada às exigências do meio rural, seria capaz de manter o rurícola no campo, dando-lhe uma formação voltada para a produção e ao amor à Pátria.

\section{Considerações finais}

Ao defender a educação para o patriotismo, a instrução aos pequenos produtores rurais e a difusão de valores morais, que exaltassem os valores coletivos e não individuais, fica patente a ideia defendida por Torres "de promover modificações preservando uma dada estrutura social e política sedimentada" (REZENDE, 2000, p.47). A ênfase na preservação do homem no campo, das contingências de um país agrícola pautado na pequena propriedade era necessária para conter o perigo do latifúndio e os desafios que a grande propriedade poderia trazer em termos de desestruturação da ordem social e da legislação vigentes à época.

Estas proposições de Torres não se restringiram ao debate intelectual, elas fizeram parte de seu projeto de reforma constitucional, que incluía outros pontos de estimada importância, como de que o ensino "leigo fosse ministrado nos estabelecimentos públicos", de que "o ensino primário e profissional agrícola, no campo" fossem gratuitos e ainda que os governos das províncias e o federal promovessem "a educação gratuita, até os cursos superiores dos brasileiros" que demonstrassem capacidade (TORRES, 1978, p. 374).

Pelo que pudemos constatar grande parte da essência do pensamento de Alberto Torres contribuiu significativamente para a origem do Ruralismo Pedagógico. 
Por esse motivo devemos considerar que, ideologicamente, o Ruralismo Pedagógico, por estar vinculado a correntes sócio-políticas e culturais da época, como o nacionalismo de Alberto Torres, fortaleceu a visão fisiocrata, a qual acreditava estar na produção agrícola, a origem da riqueza.

Precisamos salientar também que o grande equívoco do Ruralismo Pedagógico estava em supor que a educação seria um instrumento poderoso para manter o homem no campo, considerando-o como incapaz de optar em residir na zona rural ou na zona urbana.

Quanto as propostas de educação rural elaboradas pelo VII Congresso Brasileiro de Educação, o seu verdadeiro sentido serviu para reforçar o ideal da elite governante do país, que tinha como meta, manter a população rural alijada do poder político.

Recebido em 02 de outubro de 2013. Aprovado em 04 de dezembro de 2013.

\section{Referências}

ALMEIDA, R. G. A política de educação de Alberto Torres. Revista Brasileira de Estudos Pedagógicos. Rio de Janeiro, v. 2, nº 5, p. 212-220, nov. 1944.

BEZERRA NETO, L. Avanços e retrocessos da educação rural no Brasil. (Tese de Doutorado). UNICAMP, Campinas, 2003.

BOMENY, H. Os intelectuais da educação. Rio de Janeiro: Jorge Zahar, 2001.

CALAZANS, M. J. Costa. Para compreender a educação do estado no meio rural Traços de uma trajetória. In: THERIER, Jacqes; DAMASCENO; Maria Nobre. Educação e escola no campo. Campinas: Papirus, 1993.

COSTA, E. Viotti. Da monarquia à república: momentos decisivos. $7^{\mathrm{a}}$ edição, São Paulo: Editora da Unesp, 1999.

CUNHA, L. A. A universidade temporã. O ensino superior, da colônia à era Vargas. $3^{\text {a }}$ edição, São Paulo: Editora da Unesp, 2007.

FAUSTO, B. História concisa do Brasil. São Paulo: Edusp; Imprensa oficial, 2001.

FERNANDES, F. A etnologia e a sociologia no Brasil. São Paulo: Anhembi, 1958.

LAMOUNIER, B. Da independência a Lula: dois séculos de política brasileira. São Paulo: Angurium, 2005.

LEAL, V. N. Coronelismo, enxada e voto: o município e o regime representativo no Brasil. $5^{a}$ edição, São Paulo : Alfa-Omega, 1986

LEITE, S. Celani. Escola Rural: urbanização e políticas educacionais. $2^{a}$. Edição, São Paulo: Cortez, 2002. (Coleção Questões da Nossa Época; v. 70).

MARSON, A. A ideologia nacionalista em Alberto Torres. São Paulo: Duas Cidades, 1979. 
MARTINI, R. Ramos. Alberto Torres e a organização da nação. (Dissertação de Mestrado). Faculdade de Ciências e Letras, Universidade Estadual Paulista, Araraquara, 2002 .

MORAES, C. S. Vidigal. O ideário republicano e a educação: uma contribuição a história das instituições. Campinas: Mercado de Letras, 2006.

NISKIER, A. Educação brasileira: 500 anos de história, 1500-2000. São Paulo: Melhoramentos, 1989.

PALMEIRA, M. J. de Oliveira e outros. Educação e a construção da cidadania do homem do campo. Salvador: EGBA: 1990.

REZENDE, M. J. Organização, coordenação e mudança social em Alberto Torres. Estudos de Sociologia, n.8, p.35-58, 2000.

ROCHA, M. B. Mendes da. Matrizes da modernidade republicana: cultura política e pensamento educacional no Brasil. Campinas: Autores Associados; Brasília: Editora Plano, 2004.

SEVCENKO, N. Literatura como missão. Tensões sociais e criação cultural na Primeira República. $4^{a}$ edição. São Paulo: Brasiliense, 1995.

SOUZA, Rosa Fátima Espaço da educação e da civilização: origens dos Grupos escolares no Brasil. In: ALMEIDA, J. S.; SOUZA, R. F.; VALDEMARIN, V. T. O legado educacional do século XIX. Araraquara, Unesp - Faculdade de Ciências e Letras, 1998. pp. 19-62

SOUZA, Ricardo L. Nacionalismo e autoritarismo em Alberto Torres. Sociologias, Porto Alegre, ano 7, n 13, p. 302-323, jan/jun, 2005.

SZMRECSÁNYI, T.; QUEDA, A. Vida rural e mudança social. Companhia Editora Nacional: São Paulo, 1976.

ROMANELLI, O. de Oliveira. História da educação no Brasil. 10 edição, Vozes: Petrópolis, 1988.

SPEYER, A. M. Educação e Campesinato: uma educação para o homem do meio rural. Edições Loyola, São Paulo: 1983.

TORRES, A. A organização nacional. $3^{\text {a }}$ edição, São Paulo: Editora Nacional, 1978.

O problema nacional brasileiro. $4^{\mathrm{a}}$ edição, São Paulo: Editora nacional; Brasília: Editora da Universidade de Brasília, 1982.

TOTTI, M. A. Raízes do pensamento educacional de Fernando de Azevedo. (Mestrado em Educação Escolar). Araraquara, Faculdade de Ciências e Letras, Universidade Estadual Paulista, 2003.

\section{Notas}

\footnotetext{
${ }^{1}$ A República café com leite como foi convencionalmente conhecida constituía uma relação muito mais diversificada e complexa. Conforme explica Costa (1999, p.396), desde o início do movimento republicano a própria coalizão entrou em choque, pois os diversos setores progressistas da lavoura, fazendeiros de café, elementos ligados a incipiente indústria não tinham a mesma ambição e essas divergências repercutiam no Parlamento e eclodiam em movimentos descontentes desde monarquistas até republicanos insatisfeitos.
}

2 Essa aliança posta em prática pelo presidente Campos Salles (1898-1902), denominada de “política dos governadores", tinha como desafio estabilizar os mecanismo de governo a fim de equacionar problemas 
econômicos urgentes, tendo em vista, a contínua queda no valor das exportações e da perda de credibilidade internacional. Porém, segundo Lamounier (2005, p. 102) “a 'política dos governadores' agravou o déficit de legitimidade da Primeira República, em particular aos olhos da classe média e dos novos grupos políticos em formação no meio urbano" .

$\underline{3}$ O clientelismo caracterizava-se por uma troca de favores entre os coronéis através do voto de cabresto, mantido por uma relação de subordinação e dependência do eleitor para com o coronel, para maiores detalhes desse modo de fazer política observar: (LEAL, 1986).

4 Torres foi profundo crítico da importação da mão de obra estrangeira. Para ele "a necessidade de capitais e de braços estrangeiros era um dos abrigos a que se tinham acolhido a nossa indolência e o nosso despreparo, em face dos problemas da nossa economia" (TORRES, 1982, p.14).

5 Em um período que pouco, ou quase nada, falava-se em preservação dos recursos naturais e meio ambiente, Alberto Torres destaca uma prática muito atual e utilizada por Governos preocupados com a questão ambiental que é o reflorestamento, segundo Torres (1982, p.92) "O reflorestamento das regiões devastadas é, aliás, um velho costume europeu”. Além do reflorestamento, quando governador do Estado do Rio de Janeiro foi de sua iniciativa a construção de canais de saneamento na baixada fluminense, preocupação política até então jamais vista.

6 Segundo Rezende (p. 40, 2000),Torres considerava Jeferson, Hamilton e Madison, como grandes detectores de problemas e construtores de soluções.

7 A crítica da alienação deve ser entendida na acepção de Torres, pois o precursor da sociologia entendia o termo no seu sentido original, de estar alheio, conforme explica Marson: "alienação significa, aqui, pairar no ar, divagar, desvairar-se, ilustrar-se" (1979, p.119).

8 $\quad$ Segundo Fernandes (1958, p.197) “Alberto Torres foi o autor cujas obras conseguiram estabelecer tipicamente a ligação entre a análise histórica e as intenções pragmáticas, inerentes a semelhantes orientações ideológicas e utópicas... Ele ocupa o papel de pioneiro na formulação pragmática do pensamento sociológico do Brasil”.

9 O analfabetismo generalizado e o baixo rendimento escolar eram visto pelos republicanos como uma herança política do Regime Imperial, na qual se mantinha o povo sem instrução para impedi-lo de participação na vida política. Neste caso, o alargamento da participação política era fundamental para os anseios da nascente República e para sua legitimação (MORAES, 2006).

10 O autor está se referindo a Alberto Torres.

11 Torres acreditava que a educação é um elemento fundamental de unidade no país, em especial, quando utilizada a língua pátria. Assim ele proclama que o "governo federal deve, como guarda da soberania e unidade nacional, impor o ensino, talvez exclusivo, da língua nacional em todas as escolas primárias do país” (TORRES, 1978, p.119). Essa visão é importante, pois no período começava a constituir-se zonas de imigrantes que tinham escolas que ensinavam em sua língua de origem e força já no período do Estado Novo, o Estado brasileiro a estabelecer a política de nacionalização do ensino. Outro aspecto interessante é que Torres entende a língua como expressão de nossa cultura, por isso a preocupação com a língua nacional como forma de unidade.

12 Segundo Souza (1998), a implantação da escola moderna sempre se ressentiu de um esforço coletivo, pois não se caracterizava como prioridade governamental. As iniciativas reivindicatórias por um novo modelo escolar partiam de vozes isoladas como intelectuais, advogados e educadores, das quais, tiveram maior entonação na figura de Gabriel Prestes. Somente no período de 1894 e 1910 é que "foram instalados 101 grupos escolares no Estado de São Paulo, 24 na capital e 77 no interior. Apenas 35 edifícios haviam sido especialmente construídos para a escola, a maioria deles eram do Estado e cerca de 1/3 alugados pelas municipalidades" (SOUZA, 1998, p.49). 
13 Torres (1978) fez duras críticas a nossa primeira Constituição Republicana, por não se caracterizar em uma lei original, mas uma mera adaptação de instituições estrangeiras, tendo como modelo a Constituição dos Estados Unidos.

14 Torres (1982) avaliava que uma das poucas coisas com um mínimo de organização foi a escravidão, muito diferente da realidade vivenciada na República.

$15 \mathrm{O}$ movimento para pôr fim à migração do homem para a cidade visava solucionar os problemas de ordem climática, os quais não foram contornados, devido às medidas não terem sido tomadas em tempo hábil. A distância entre o centro do poder e a região agrícola mais rica do país retardou as medidas saneadoras. Não foram construídos açudes suficientes para garantir a irrigação das lavouras, que eram cuidadas de forma artesanal. A queimada era utilizada como forma de limpar o terreno, e ainda é praticada até hoje. Uma reforma agrária era necessária, mas também não foi realizada (SPAYER, 1983, p. 68). 